\title{
IMPLEMENTASI PENILAIAN AUTENTIK KURIKULUM 2013 PADA RAPOR ONLINE DI SMK NEGERI 6 MALANG
}

\author{
Galih Sudiyanto $^{1}$, Eddy Sutadji ${ }^{2}$, Eddy Rudiyanto ${ }^{3}$ \\ 1,2,3 Universitas Negeri Malang \\ sudiyantogalih@gmail.com
}

\begin{abstract}
One factor that is considered difficult to implement by teacher in the 2013 Curriculum is authentic assessment. However, this can be overcome with an online report that was initiated by Dispendik for all schools in the city of Surabaya. The study aims to see the implementation of authentic assessment in the 2013 Curriculum at a school that have implemented online report in Malang, namely SMK Negeri 6 Malang. The method used was a case study using questionnaires, interviews and documentation. The validity of research findings was examined using data triangulation technique. The respondents were productive teachers who teach automotive skills in the same class so that there is a correlation between the data obtained from the teachers and the students. The result shows that the implementation of authentic assessment in the 2013 Curriculum at SMK Negeri 6 Malang is in good category and teachers were greatly assisted by the online report.
\end{abstract}

Keywords: authentic assessment, 2013 curriculum, online report

\begin{abstract}
ABSTRAK
Salah satu faktor yang sulit untuk dilaksanakan oleh guru dalam Kurikulum 2013 adalah penilaian autentik. Penelitian ini bertujuan untuk melihat penerapan penilaian autentik Kurikulum 2013 pada sekolah yang sudah menerapkan rapor online di Kota Malang. Rancangan penelitian ini menggunakan deskriptif kualitatif dengan pendekatan studi kasus yang dilaksanakan di SMK Negeri 6 Malang. Metode pengumpulan data menggunakan instrumen angket, wawancara dan dokumentasi. Pengecekan keabsahan temuan penelitian menggunakan teknik trianggulasi data. Responden adalah guru produktif keahlian Otomotif yang mengajar pada kelas yang sama sehingga ada korelasi antara data yang didapat dari guru dan siswa. Hasil penelitian menunjukkan bahwa: (1) Pemahaman guru SMK Negeri 6 Malang terhadap penilaian autentik Kurikulum 2013 sangat baik sebesar 90\%, (2) Pelaksanaan penilaian autentik Kurikulum 2013 oleh guru SMK Negeri 6 Malang sudah baik sebesar 70, (3) Manajemen rapor online oleh Tim IT sudah baik dalam memudahkan pelaksanakan penilaian autentik Kurikulum 2013 di SMK Negeri 6 Malang sebesar 80\%.
\end{abstract}

Kata kunci: penilaian autentik, kurikulum 2013, rapor online

\section{PENDAHULUAN}

Permendikbud Nomor 66 Tahun 2013 tentang Standar Penilaian Pendidikan, menjelaskan bahwa penilaian autentik merupakan penilaian yang dilakukan secara komprehensif untuk menilai mulai dari masukan (input), proses dan keluaran (output) pembelajaran. Penilaian autentik pada pelaksanaan Kurikulum 2013 menggunakan perpaduan berbagai teknik penilaian. Hal ini dirasakan oleh guru sebagai suatu yang sulit untuk dilaksanakan secara penuh karena sangat menyita waktu. Dispendik Surabaya melakukan terobosan dengan menyediakan rapor online untuk semua sekolah di Kota Surabaya dan terbukti berhasil membantu pelaksanaan Kurikulum 2013 khususnya penilaian autentik. Terobosan serupa seharusnya juga dapat dipertimbangkan oleh Dispendik kota Malang. Namun, tetap harus tetap melihat kesiapan guru yang menjadi pelaksana di lapangan. Penelitian ini sangat membantu untuk melihat bagaimana pemahaman guru dan kemampuan guru dalam menerapkan penilaian autentik Kurikulum 2013 serta peranan rapor online sebagai pendukung. Di negara lain pun penilaian dianggap sangat penting dalam dunia pendidikan seperti pada disampaikan jurnal Harry Torrance (2013) bahwa "Recently assessment has been singled 
out as a key mechanism for monitoring and intervening in the educational process. In particular, claims are being made that new forms of assessment will be able to drive teaching and learning in more positive ways than was originally associated with narrower testing programs".

\section{METODE}

Rancangan penelitian ini dilaksanakan dengan menggunakan rancangan penelitian deskriptif kualitatif dengan menggunakan pendekatan studi kasus. Studi kasus merupakan tipe pendekatan dalam penelitian yang penelaahannya kepada satu kasus dilakukan secara intensif, mendalam, mendetail dan komprehensif (Faisal, 1980: 22). Penelitian ini menggunakan instrumen jenis angket atau kuesioner, wawancara, dan dokumentasi. Pengumpulan data dengan menggunakan angket kepada guru dan siswa, seta teknik dokumentasi dan wawancara yang ditujukan kepada guru SMK Negeri 6 Malang sebagai klarifikasi. Responden adalah guru produktif keahlian Otomotif yang mengajar pada kelas yang sama sehingga ada korelasi antara data yang diperoleh dari guru dan siswa. Populasi penelitian ini kelas keahlian Otomotif kelas X Teknik Alat Berat SMK Negeri 6 Malang. Pengecekan keabsahan hasil penelitian ini menggunakan teknik trianggulasi. Teknik trianggulasi yang paling banyak digunakan ialah pemeriksaan melalui sumber lain. Analisis statistik berupa perhitungan persentase dari skor angket yang telah disebar. Perhitungan tersebut digunakan untuk menentukan persentase jawaban dari item untuk setiap pertanyaan yang dijawab responden. Oleh karena itu, menggunakan rumus persentase (Daryanto, 2012: 180) sebagai berikut:

$B=\frac{F}{N} x 100 \%$

dimana:

$\mathrm{B}=$ Persentase jawaban responden untuk tiap butir soal

$\mathrm{F}=$ Frekuensi jawaban pertanyaan responden

$\mathrm{N}=$ Jumlah total responden

Hasil nilai persentase yang diperoleh kemudian dideskripsikan dengan kalimat yang bersifat kualitatif, seperti yang ditunjukkan pada Tabel 1 .

Tabel 1. Konversi Kualitatif Jawaban Responden

\begin{tabular}{ll}
\hline Skor & Kategori \\
\hline $86 \%-100 \%$ & Sangat Baik \\
$66 \%-85 \%$ & Baik \\
$51 \%-65 \%$ & Cukup \\
$0 \%-50 \%$ & Kurang \\
\hline
\end{tabular}

\section{HASIL DAN PEMBAHASAN}

Sebanyak $60 \%$ responden guru adalah lulusan sarjana pendidikan, $20 \%$ lulusan non pendidikan dan 20\% lulusan pasca sarjana. Dari paparan data di atas menunjukkan bahwa sebagian besar guru yang mengajar di program keahlian Alat Berat SMK Negeri 6 Malang memiliki jenjang pendidikan setara Sarjana Pendidikan. Data responden guru seperti ditunjukkan pada Gambar 1 di bawah ini.



Gambar 1. Diagram Pendidikan Terakhir Guru 
Persepsi terhadap kurikulum 2013 dan penilaian autentik masih terdapat perbedaan di kalangan guru itu sendiri. Perbedaan antara kurikulum 2013 dan KTSP diakui guru dengan sangat signifikan dimana 90\% guru mengatakan ada perbedaan dan hanya $10 \%$ yang mengatakan tidak ada perbedaan. Hal tersebut ditunjukkan pada Gambar 2

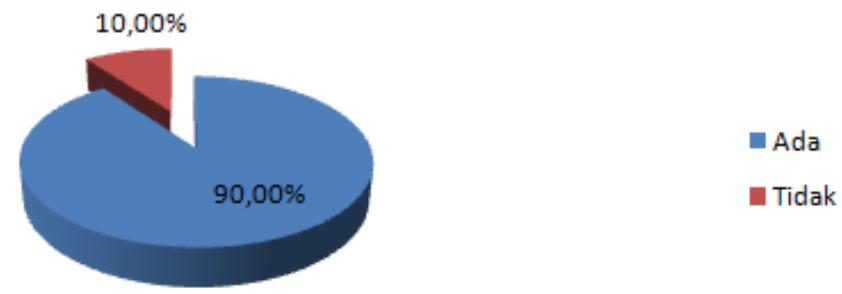

Gambar 2. Diagram Perbedaan Kurikulum 2013 dan KTSP Menurut Guru

Persiapan guru dalam melaksanakan penilaian autentik pada kurikulum 2013 diketahui bahwa seluruh guru melakukan perencanaan penilaian. Data yang diperoleh menunjukkan bahwa dalam menyusun perencanaan tersebut guru memiliki fokus yang berbeda-beda yaitu: sebanyak $66,67 \%$ memilih siswa sebagai fokus penilaian dalam perencanaannya, $25 \%$ fokus pada mata pelajaran, dan $8,33 \%$ yang memilih fokus lain dalam penilaian.
Tingkat penerapan penilaian autentik yang dilaksanakan oleh guru menunjukkan bahwa sebanyak $40 \%$ guru selalu menggunakan penilaian autentik, sedangkan sebanyak $30 \%$ guru sering menggunakannya, dan sebanyak $30 \%$ jarang menggunakan penilaian autentik. Hal tersebut menujukkan bahwa tidak ada guru yang tidak pernah menggunakan penilaian autentik, seperti yang disajikan pada Gambar 3 di bawah ini.
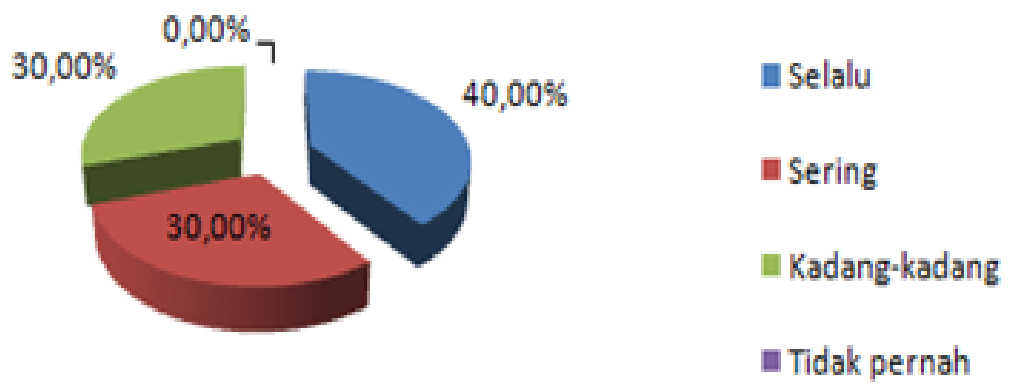

Gambar 3. Diagram Pelaksanaan Penilaian Autentik Kurikulum 2013

Pendapat guru terhadap penerapan rapor online kurikulum 2013 menunjukkan bahwa sebanyak $60 \%$ guru menyatakan rapor online sangat membantu, sebanyak $20 \%$ menyatakan hanya sedikit saja membantu proses penilaian autentik, sementara sebanyak $20 \%$ lainnya menyatakan penerapan rapor online sama aja atau dapat dikatakan tidak membantu dalam pelaksanaan penerapan autentik.

Data hasil rata-rata keseluruhan siswa kelas X Alat Berat SMK Negeri 6 Malang sebagaimana ditunjukkan pada Gambar 4 dapat disimpulkan dalam penerapan guru terhadap penilaian autentik Kurikulum 2013 dan rapor online dikategori terlaksana dimana mayoritas jawaban ada pada "Selalu" (38,04\%) dan "Kadang-kadang" (48,04\%), sedangkan untuk jawaban "Tidak Pernah" (13,92\%). Data diatas menunjukkan penerapan Penilaian Autentik Kurikulum 2013 pada Rapor Online di SMK Negeri 6 Malang sudah terlaksana, namun belum pada kategori memuaskan. 



Gambar 4. Diagram Penilaian Autentik pada Siswa dalam Penilaian Autentik

Data yang diperoleh pada hasil penelitian apabila dilihat dari sisi pengalaman guru dalam dunia pendidikan khususnya mengajar sudah menunjukkan tingkat yang sangat baik. Latar belakang pendidikan semua guru memenuhi kriteria pendidik SMK sesuai Peraturan Pemerintah Nomor 32 Tahun 2013 tentang perubahan atas Peraturan Pemerintah Nomor 19 Tahun 2005 tentang Standar Nasional Pendidikan pendidikan guru SMK minimum adalah diploma empat (D-IV) atau sarjana (S1).

Hasil penelitian memperlihatkan bahwa pemahaman guru SMK Negeri 6 Malang terkait penilaian autentik Kurikulum 2013 sudah baik. Pemahaman yang baik guru SMK Negeri 6 Malang terhadap penilaian autentik Kurikulum 2013 dapat dilihat dari beberapa temuan penelitian yang telah dipaparkan. Guru sudah memahami "apa dan bagaimana" Kurikulum 2013. Pemahaman guru terhadap Kurikulum 2013, terlihat pada kemampuan guru dalam membedakan Kurikulum 2013 dengan Kurikulum Tingkat Satuan Pendidikan (KTSP) baik secara umum maupun pada penilaian autentik. Mayoritas guru (90\%) menyatakan ada perbedaan antara Kurikulum 2013 dengan KTSP dan menyatakan bahwa perbedaan ada pada proses pembelajaran dan penilaian hasil pembelajaran. Penilaian autentik menurut pemahaman guru adalah penilaian nyata yang dilaksanakan secara komprehensif. Pendapat responden sesuai dengan pengertian penilaian autentik Permendikbud Nomor 66 Tahun 2013 tentang Standar Penilaian Pendidikan bahwa penilaian autentik merupakan penilaian yang dilakukan secara komprehensif untuk menilai mulai dari masukan (input), proses, dan keluaran (output) hasil pembelajaran dan Permendikbud Nomor. 104 Tahun 2014 bahwa penilaian autentik adalah bentuk penilaian yang menghendaki peserta didik menampilkan sikap, menggunakan pengetahuan dan keterampilan yang diperoleh dari pembelajaran dalam melakukan tugas di situasi yang sesungguhnya.

Hal penting yang perlu diperhatikan pada pelaksanaan penilaian autentik kurikulum 2013 adalah bagaimana perencanaan, proses sampai pada kegiatan evaluasi penilaian sebagai bahan pertimbangan untuk perencanaan penilaian berikutnya. Pada tataran perencanaan semua guru melakukan perencanaan penilaian autentik dan tertuang pada Rencana Pelaksanaan Pembelajaran (RPP) masing-masing. Penilaian lebih mudah dilaksanakan karena penilaian terkonsep dan terintegrasi dengan proses pembelajaran. Namun, masih terdapat $20 \%$ guru tidak melakukan perencanaan penilaian sampai pada merencanakan remedial dan pengayaan. Kunandar (2014: 333) menjelaskan bahwa salah satu prinsip yang harus diperhatikan dalam pembelajaran tuntas yang diterapkan pada Kurikulum 2013 adalah merancang berbagai kegiatan pembelajaran remidial untuk peserta didik dengan bervariasi.

Pelaksanaan proses pembelajaran kurikulum 2013 seluruh guru melaksanakan rencana pembelajarannya, walaupun $30 \%$ guru diantaranya menyebutkan bahwa perencanaan yang sudah disusun tidak semua dapat terlaksana. Kegiatan Belajar Mengajar (KBM) memang bukanlah benda mati yang harus $100 \%$ ikut rencana guru. Hal ini disebabkan respon yang berbeda-beda dari siswa saat guru memberikan treatment dan menuntut guru untuk membuat antisipasi respon yang berbeda pula (Suryadi, 2008).

Semua guru sudah melaksanakan dan melakukan kegiatan evaluasi penilaian autentik 
Kurikulum 2013, namun ada 30\% guru yang belum melaksanakannya secara penuh. Semua guru yang belum melaksanakan penilaian autentik secara penuh beralasan waktu yang tidak mencukupi untuk melakukan setiap penilaian. Guru-guru berpendapat seharusnya ada penyederhanaan penilaian autentik sehingga memungkinkan untuk dilaksanakan secara penuh. Nuh (2014) menyatakan bahwa selama ini guru terbiasa memberikan nilai dengan kirakira sehingga saat dituntut memberikan penilaian autentik masih membutuhkan banyak waktu dan pembiasaan.

SMK Negeri 6 Malang memiliki 2 jenis rapor online yaitu rapor online KTSP dan rapor online Kurikulum 2013. Mayoritas guru mengapresiasi adanya rapor online Kurikulum 2013. Penilaian autentik yang begitu rumit sampai pada pelaporan pada rapor dimudahkan dengan rapor online yang dirasa lebih cepat, praktis dan efisien. Guru dapat mengakses rapor online kapan saja dan dimana saja. Pemrosesan nilai menjadi nilai rapor bahkan sampai deskripsi nilai, menjadi lebih cepat tanpa dipersulit administrasi. Penelitian Herrington (2006) juga menyatakan bahwa penilaian autentik memang cocok dengan multimedia seperti pernyataannya "The implication of these findings for educational practice are that authentic assessment can be used within interactive multimedia learning environments, albeit not totally contained within the software itself'. Namun begitu, beberapa guru kurang memanfaatkannya dengan hanya mengakses rapor online Kurikulum 2013 di saat mendekati penyerahan rapor saja. Permendikbud Nomor. 66 Tahun 2013 tentang Standar Penilaian Pendidikan menyatakan bahwa peniaian hasil belajar oleh pendidik yang dilakukan secara berkesinambungan bertujuan untuk memantau proses dan kemajuan belajar peserta didik serta untuk meningkatkan efektivitas pembelajaran. Anjuran serupa juga keluarkan oleh Dispendik Surabaya (2014) yang sudah menerapkan Rapor Online untuk semua sekolah, bahwa pengisian rapor online hendaknya setiap kali selesai penilaian.
Dispendik Surabaya (2014) menjelaskan bahwa hak akses rapor online guru sendiri ada 2 jenis, yaitu: (1) Guru sebagai wali kelas: Akses wali kelas bisa melihat (read only) tanpa bisa mengedit nilai seluruh mata pelajaran peserta didiknya, (2) Guru sebagai pengampu mata pelajaran: Akses guru mata pelajaran bisa upload nilai dan editing nilai, namun hanya pada mata pelajaran dan kelas yang diajar saja.

Dilihat dari sisi kemampuan mengakses rapor online Kurikulum 2013, semua guru sudah menguasai pengaksesan rapor online karena rapor online sudah ada sebelum Kurikulum 2013 di SMK Negeri 6 Malang. Selain itu, diawal penggunaannya guru-guru sudah mendapatkan sosialisasi tentang rapor online.

Siswa kelas X Alat Berat SMK Negeri 6 Malang sebagai obyek penilaian guru menyatakan bahwa keterlaksanaan penilaian autentik sampai pada pelaporan dalam bentuk rapor online sudah baik. Hanya sekitar 13,92\% siswa yang menjawab "tidak pernah" yang kemungkinan berasal dari ketidaktahuan siswa tentang akses rapor online, dimana mereka adalah siswa kelas $\mathrm{X}$ yang baru menggunakan rapor online.

\section{SIMPULAN}

Hasil analisis dan pembahasan yang diuraikan di atas dapat disimpulkan bahwa: (1) Pemahaman guru SMK Negeri 6 Malang terhadap penilaian autentik Kurikulum 2013 sangat baik sebesar 90\%, (2) Pelaksanaan penilaian autentik Kurikulum 2013 oleh guru SMK Negeri 6 Malang sudah baik sebesar 70, (3) Manajemen rapor online oleh Tim IT sudah baik dalam memudahkan pelaksanakan penilaian autentik Kurikulum 2013 di SMK Negeri 6 Malang sebesar $80 \%$.

\section{DAFTAR RUJUKAN}

Arikunto, Suharsimi. 1997. Prosedur Penelitian Suatu Pendekatan praktek. Bandung: PT. Cipta Rineka. 
Daryanto. 2012. Evalusi Pendidikan. Jakarta: Rineka Cipta.

Dispendik Kota Surabaya. 8 Oktober 2014. Sosialisasi Rapor Online. (Online). (http:/www.dispendiksurabaya.go.id). Diakses 7 April 2015.

Faisal, Sanapiah. 1980. Format-format Penelitian Sosial. Semarang: CV. Rajawali.

Herrington. 2006. Authentic Assessment and Multimedia: how university students respond to a model of authentic assessment.(http:/www.sagepub.com).

Diakses 13 Mei 2015.

Kunandar. 2014. Penilaian Autentik (Penilaian Hasil Belajar Peserta Didik Berdasarkan Kurikulum 2013). Jakarta: PT. Grafindo Persada.

Moleong, Lexy J. 2013. Metodologi Penelitian Kualitatif. Bandung: PT. Remaja Rosdakarya.

Nuh, Mohammad. 25 Juli 2014. Ini Guru Kesulitan cara Penilaian Autentik Kurikulum 2013. (Online). (http:/www.nasional.republika.co.id). Diakses 25 Januari 2014
Peraturan Pemerintah Nomor. 32 Tahun 2013 tentang perubahan atas Peraturan Pemerintah Nomor. 19 Tahun 2005 tentang Standar Nasional Pendidikan.

Permendikbud Nomor. 66 Tahun 2013 tentang Standar Penilaian Pendidikan. 2013. Jakarta: Kemendikbud.

Permendikbud Nomor. 104 Tahun 2013 tentang Penilaian Hasil Belajar oleh Pendidik pada Pendidikan Dasar dan Pendidikan Menengah

Suryadi, Didi. 2008. Improvisasi dalam Proses Pembelajaran.

(Online). (http:/www.ArchiveDidaktik.com). Diakses 7 April 2015.

Torrance, harry. 2013. Combining Measurement-Driven Instruction With Authentic Assessment: Some Initial Observations of National Assessment in England and Wales. (http:/www.tandfonline.com). Diakses 13 Mei 2015.

Tim Universitas Negeri malang. 2010. Pedoman Penulisan Karya Ilmiah Edisi Kelima. Malang: Universitas Negeri Malang. 